\title{
Physico-chemical Characteristics of Different Types of Mango (Mangifera Indica L.) Fruits Grown in Drafur Regions and its Use in Jam Processing
}

\author{
Mohammed A.Y. Abdualrahman \\ Department of Food Technology, Nyala Technological College, Nyala, Southern Darfur State, Sudan
}

\begin{abstract}
Mango (Mangifera indica L.), is king of fruits due to its high palatability, excellent taste and flavour. The aim of this study was to evaluate the physico-chemical characteristic of different types of mango fruits grown in Darfur regions and its use in jam processing. For this, different types of mango fruits were carried out in term of physico-chemical analysis. The physical characteristics results indicated that KMF had higher contents of flesh, length, width and volume $(82.4 \pm 0.04,125 \pm 0.01,95 \pm 0.02$ and $300 \pm 0.01)$, respectively. The proximate analysis of mango fruits was crude protein $(0.74 \pm 0.02-0.82 \pm 0.03 \%)$, ash (1.35 $\pm 0.01-1.7 \pm 0.02 \%)$, crude fat $(0.29 \pm 0.02-0.38 \pm 0.01 \%)$, crude fiber $(4.2 \pm 0.01$ $4.5 \pm 0.01 \%)$ and total carbohydrates (14.1 $\pm 0.01-15.4 \pm 0.01 \%)$. The NMJF, EMJF and KMJF contained 67,67 and $66.8 \%$ TSS, respectively. The contents of total and reducing sugars of NMJF, EMJF and KMJF were $(12.3,12.8$ and $12.8 \%)$ and $(4.6,4.8$ and $4.5 \%)$, respectively. On other hand, the titratable acidity and $\mathrm{pH}$ values were $(0.35,0.37$ and $0.34 \%)$ and $(3.5,3.6$ and $3.4 \%)$, respectively; while, the contents of moisture and ash were $(45.8,46$ and $45.6 \%)$ and $(0.32,0.34$ and $0.33 \%$ ), respectively. The sensory analysis revealed that all types of jams were accepted by the panelist; also, there are no significant differences as regard to appearance, colour, flavour and overall acceptability.
\end{abstract}

Key words: Mango fruits, physico-chemical characteristics, jam processing, sensory evaluation

Science International, 1 (5): 144-147, 2013

\section{INTRODUCTION}

Mango (Mangifera indica L., Anacardiaceae), is one of the most profitable crops in tropical and subtropical regions in the world. Originating in the Himalayan foothills of Indian-Myanmar region, it has been cultivated for more than 4,000 years and is renowned for its excellent flavour, attractive, fragrance and high nutritional value ${ }^{1}$. Mango can play an important role in balancing human diet by providing about $64-86$ calories of energy per $100 \mathrm{~g}$ and when consumed regularly, can be a valuable dietary source of many phytochemical compounds. ${ }^{1}$. In addition, among many other components, the ascorbic acid content makes the fruit an excellent source of vitamin $\mathrm{C}$, its content varying from 32 to $200 \mathrm{mg}$ per $100 \mathrm{~g}$ of edible pulp. Over the last decade (1991-2001), mango growing area has increased by $42.5 \%$, due to the interest increasing in the fruit's fresh ass well as processed consumption. The world production of the fruit is estimated to be over $23.4 \times 10^{6}$ tones per year and is expected to increase 1 . Mango (Mangifera indica L.) is king of fruits due to its high palatability, excellent taste and flavour. Mango pulp is rich in the essential minerals,

Corresponding Author: Mohammed Adam Yahya Abdualrahman, Department of Food Technology, Nyala Technological College, Nyala, Southern Darfur State, Sudan vitamins and other nutritive factors. Due to shorter shelf life of the mango, it must be converted into various processed products ${ }^{2}$. In Sudan, area and production were 16238 ha and 651000 tons, respectively. The aim of this study was to evaluate the physico-chemical characteristic of different types of mango fruits grown in Darfur regions and its use in jam processing.

\section{MATERIALS AND METHODS}

Collection of the samples: Different types of mango fruits were collected from gardens located at Nyala, Edelfursan and Kaboom, Southern Darfur State, Sudan in the years, 2012. The fruits were carefully cleaned and freed from foreign materials.

Physical characteristics: Each sample of mango fruits was peeled. The peel, seed and pulp are separated and each fraction was then weighed using sensitive balance. Fruit volume was determined using rapeseeds displacement volumeter method according to Pyler ${ }^{4}$. However, this method was modified by using sesame seeds instead of the rapeseeds.

Proximate analysis: The proximate analysis of each sample of mango fruits was conducted for the contents of 
moisture, ash and crude fat in triplicate according to the $\mathrm{AOAC}^{5}$. Crude protein was calculated as $\mathrm{N} \times 6.25$ according to the $\mathrm{AOAC}^{6}$. Crude fiber was carried out using acid/alkali digestion method according to the $\mathrm{AOAC}^{7}$. Total carbohydrate content was calculated by subtracting the previous components from 100 .

Preparation of mango jam fruits: A Fully mature mango fruits from each sample were peeled, sliced by fruit and vegetable cutter machine (KG-40. Nihon Conk CO. LTD. Japan) after discarding the seeds. The slices were blanched. Mango fruits puree was obtained by passing the blanched slices through narrow orifices of pulper (PPT-180. Seikensha Co. LTD. Japan). The pH and Total Soluble Solids (TSS) of the puree were determined. Addition of pectin to the jam was used according to the method described by Saeed and Elmubarak ${ }^{8}$. In this method, 10 parts of commercial pectin were mixed with 20 parts of sugar in a dry container and the mixture was added slowly to 70 parts of water which was heated in advance to boiling with constant agitation till the pectin was completely dissolved. Boiling is desirable in order to cause intimate mixing of the mango fruits pulp, pectin and sugar to partially concentrate the products by evaporation of excess water using aluminum open-kettle. An (Atago, N1, brix $0 \sim 32$, Japan) refractometer was used to determine the end point of jam (total soluble solids, 67\%). The hot jam was filled in glass jars, tightly closed without delay, then putted upside down and cooled.

Jam quality analysis: The quality of jams prepared from different sample of mango fruits were examined in term of chemical composition and sensory evaluation. The $\mathrm{pH}$ was determined using (Hanna, $\mathrm{pH}$ 211, Microprocessor $\mathrm{pH}$ meter) according to the $\mathrm{AOAC}^{6}$. The total soluble solid was determined using (Atago, N1, brix $0 \sim 32$, Japan) refractometer as described by Pomeranz and Meloan ${ }^{9}$. The moisture and ash contents were conducted according to the $\mathrm{AOAC}^{5}$. The titratable acidity was carried out as citric acid. Ten grams from each sample of mango jam fruits were diluted with recently boiled water to $250 \mathrm{~mL}$ and then the solution was titrated against $0.1 \mathrm{~N}$ sodium hydroxide using phenolphthalein indicator. Reducing sugars were determined using Nelson's method in which $1 \mathrm{~mL}$ sample was pipetted in a test tube; $1 \mathrm{~mL}$ of copper reagent and $1 \mathrm{~mL}$ of Harding's reagent were then added. The content of the test tube were shaken and heated in boiling water for $10 \mathrm{~min}$. After cooling, $1 \mathrm{~mL}$ of Nelson's reagent was then added to each tube. After the addition of Nelson's reagent, the volume in the tube was completed to $10 \mathrm{~mL}$ with distilled water. The tubes were allowed to stand for $10 \mathrm{~min}$ to complete the colour development. The absorbency of the tube content was recorded at $600 \mathrm{~nm}$ against a distilled water blank tube (control) using a spectrophotometer. The sugar value was determined from the glucose standard curve plotted earlier. Reducing sugar was calculated as follow:

$$
\text { Reducing sugar }(\%)=\frac{50}{\mathrm{~V}} \times \frac{\mathrm{y}}{\mathrm{W}} \times \frac{100}{1000 \times 100}
$$

where, $\mathrm{V}$ is the volume of tested sample, $\mathrm{Y}$ is the glucose concentration and $W$ is the weight of sample.

Sensory evaluation: A panel of thirty members composed of adults male and female was used to judge the quality of jam prepared from mango fruits collected from Nyala, Edalfersaan and Kabum, using a questionnaire designed by the Department of Food Technology, Nyala Technological College, Nyala, Sudan. The panelists were asked to evaluate each sample for appearance, texture, colour, flavour and overall acceptability using a 9 point hedonic scale from 1 to 9 as follows: 1: Extremely bad; 2: Very bad; 3: Bad; 4: Fairly bad; 5: Satisfactory; 6: Fairly good; 7: Good; 8: Very good; 9: Excellent as described by Iwe ${ }^{10}$. The order of presentation of the different samples was randomized and given codes before being tested by the panelists.

Statistical analysis: The data of organoleptic evaluation of different types of mango jam fruit were subjected to analysis of variance procedure and the means were separated at 0.05 levels according to the Snedecor and Cochran ${ }^{11}$.

Table 1 shows the weight of peel, seed and flesh, length, width and volume of different types of mango fruits. For fruits peel and seed, the higher values are for EMF $(10.53 \pm 0.3$ and $7.9 \pm 0.01 \%)$, respectively and the lower values are for KMF $(10.6 \pm 0.02$ and $7.0 \pm 0.01 \%)$, respectively. The data are within the range of $(6.30 \pm 0.9-$ $13.4 \pm 1.65$ and $4.2 \pm 0.2-11.8 \pm 0.6 \%$ ), respectively reported by Snedecor and Cochran ${ }^{11}$ and lower than the range of (13-22 and 12-20\%), respectively found by Anila and $\mathrm{Radha}^{12}$. For flesh weight, the higher value is for KMF $(82.4 \pm 0.04 \%)$ and the lower value is for EMF $(81.57 \pm 0.02 \%)$. The data are within the range of $(74.6 \pm 1.3-85.9 \pm 1.5 \%)$ reported by Pleguezuelo ${ }^{1}$. On the other hand, Anila and Radha ${ }^{12}$ reported a lower value of mango fruit pulp $(58-75 \%)$. For fruit length and

\begin{tabular}{|c|c|c|c|c|c|c|}
\hline Types & $\begin{array}{c}\text { Peel weight } \\
(\%)\end{array}$ & $\begin{array}{c}\text { Seed weight } \\
(\%)\end{array}$ & $\begin{array}{c}\text { Flesh weight } \\
(\%)\end{array}$ & $\begin{array}{l}\text { Length } \\
(\mathrm{mm})\end{array}$ & $\begin{array}{l}\text { Width } \\
\text { (mm) }\end{array}$ & $\begin{array}{r}\text { Volume } \\
(\mathrm{mL})^{3}\end{array}$ \\
\hline$\overline{\text { NMF }}$ & $10.70 \pm 0.1$ & $7.2 \pm 0.03$ & $82.10 \pm 0.01$ & $101 \pm 0.01$ & $83 \pm 0.03$ & $150 \pm 0.02$ \\
\hline EMF & $10.53 \pm 0.3$ & $7.9 \pm 0.01$ & $81.57 \pm 0.02$ & $113 \pm 0.02$ & $92 \pm 0.01$ & $250 \pm 0.01$ \\
\hline KMF & $10.60 \pm 0.02$ & $7.0 \pm 0.01$ & $82.40 \pm 0.04$ & $125 \pm 0.01$ & $95 \pm 0.02$ & $300 \pm 0.01$ \\
\hline
\end{tabular}


width the higher values are for KMF $(125 \pm 0.01$ and $95 \pm 0.02)$, respectively and the lower values are for NMF $(101 \pm 0.01$ and $83 \pm 0.03)$, respectively. The data of fruit length are within the range of $(80.4 \pm 8.3-126.8 \pm 7 \%)$; while the data of fruit width are higher than the range of $(72.5 \pm 4.6-92.4 \pm 6.5 \%)$ reported by Snedecor and Cochran $^{11}$. Anila and Radha ${ }^{12}$, reported range of (8.5-9.9 and $5.6-7.7 \mathrm{~cm}$ ) for mango fruit length and width, respectively. For fruit volume, the higher value is for KMF $(300 \pm 0.01)$ and the lower value is for NMF $(150 \pm 0.02)$. The data are within the range of (150-395) found by Anila and Radha ${ }^{12}$.

The proximate analysis of different types of mango fruits is presented in Table 2. Fruit with higher moisture contents are for EMF and KMF $(78.52 \pm 0.01$ and $78.7 \pm 0.02 \%$ ), respectively and the lower content is for NMF $(77.4 \pm 0.01 \%)$, hence, this is an indication of a good shelf life. The data are within the range of (74.58-86.36 and $73-80 \%$ ) reported by Uddin et al..$^{13}$; Joseph and Aworh ${ }^{14}$, respectively. The crude protein contents of EMF and KMF $(0.74 \pm 0.02$ and $0.79 \pm 0.01 \%)$, respectively are lower than the content of NMF $(0.82 \pm 0.03 \%)$. Fruit with higher content of ash is for KMF $(1.7 \pm 0.02 \%)$ and the lower values are for NMF and EMF $(1.5 \pm 0.02$ and $1.35 \pm 0.01 \%$ ), respectively. On the other hand, the crude fat content of NMF $(0.38 \pm 0.01 \%)$ is slightly higher than the contents of EMF and KMF $(0.29 \pm 0.02$ and $0.31 \pm 0.01 \%$ ), respectively. There are no much variable in crude fiber contents among NMF, EMF and KMF $(4.5 \pm 0.01,4.2 \pm 0.01$ and $4.4 \pm 0.03 \%)$, respectively. Fruit with higher contents of carbohydrates are for NMF and EMF (15.4 \pm 0.01 and $14.9 \pm 0.03 \%)$, respectively; while, the lower content is for KMF $(14.1 \pm 0.01 \%)$.

The analysis of jam quality is presented in Table 3. The $\mathrm{pH}$ values of NMJF, EMJF and KMJF are 3.5, 3.6 and 3.4 , respectively. The data are agreement with the requirement of jam quality control and are fall within the range of (3.4-3.6) reported by Abdelwahab et al. ${ }^{15}$. The TSS of NMJF, EMJF and KMJF are 67, 67 and 66.8\%, respectively. The data are within the range of $(66-68 \%)$ found by Abdelwahab et al ${ }^{15}$. Titratable acidity of NMJF, EMJF and KMJF $(0.35,0.37$ and $0.34 \%$, respectively) are lower than the range of $(0.4-0.6)$ reported by Abdelwahab et $a l^{15}$. The moisture contents of NMJF, EMJF and KMJF are $45.8,46$ and $45.6 \%$, respectively. The data are agreement with the range of (45.2-53.7\%) reported by Abdelwahab et al ${ }^{15}$. The ash content of NMJF, EMJF and KMJF are 0.32, 0.34 and $0.33 \%$, respectively. The data are exceeds the range of $(0.1-0.2 \%)$ found by Abdelwahab et al..$^{15}$ and less than the range of (1.02-1.05\%) reported by Ahmed ${ }^{16}$. The total sugar of NMJF, EMJF and KMJF were 12.3, 12.5 and $12.8 \%$, respectively. The results are higher than the range (8.4-12\%) found by Abdelwahab et al..$^{15}$ and lower than the
Table 2: Proximate analysis of different types of mango fruits

\begin{tabular}{|c|c|c|c|}
\hline \multirow[b]{2}{*}{ Component (\%) } & \multicolumn{3}{|c|}{ Samples treatment } \\
\hline & NMF & EMF & KMF \\
\hline Moisture & $77.40 \pm 0.01$ & $78.52 \pm 0.01$ & $78.70 \pm 0.02$ \\
\hline Crude protein & $0.82 \pm 0.03$ & $0.74 \pm 0.02$ & $0.79 \pm 0.01$ \\
\hline Ash & $1.50 \pm 0.02$ & $1.35 \pm 0.01$ & $1.70 \pm 0.02$ \\
\hline Crude fat & $0.38 \pm 0.01$ & $0.29 \pm 0.02$ & $0.31 \pm 0.01$ \\
\hline Crude fiber & $4.50 \pm 0.01$ & $4.20 \pm 0.01$ & $4.40 \pm 0.03$ \\
\hline Carbohydrates & $15.40 \pm 0.01$ & $14.90 \pm 0.03$ & $14.10 \pm 0.01$ \\
\hline
\end{tabular}

NMF: Means Nyala mango fruits, EMF: Edelfursan mango fruits, KMF:

Kaboom mango fruits

Table 3: Chemical composition of mango fruit jam products

\begin{tabular}{lcrr}
\hline & Samples treatment & \\
& - & \\
Parameters & NMJF & EMJF & KMJF \\
\hline pH & 3.50 & 3.60 & 3.40 \\
TSS (\%) & 67.00 & 67.00 & 66.80 \\
Titratable acidity (\%) & 0.35 & 0.37 & 0.34 \\
Moisture content (\%) & 45.80 & 46.00 & 45.60 \\
Ash content (\%) & 0.32 & 0.34 & 0.33 \\
Total sugar (\%) & 12.30 & 12.50 & 12.80 \\
Reducing sugar (\%) & 4.60 & 4.80 & 4.50 \\
\hline
\end{tabular}

NMJF: Means Nyala mangos jam fruits, EMJF: Edelfursan mangos jam fruits, KMJF: Kaboom mangos jam fruits

Table 4: Mean score for sensory attributes of jam prepared from different types of mango fruits

Samples Appearance Texture Colour Flavour Overall acceptability

\begin{tabular}{llllll}
\hline NMJF & $8.0^{\mathrm{a}}$ & $8.3^{\mathrm{a}}$ & $8.0^{\mathrm{a}}$ & $8.7^{\mathrm{a}}$ & $8.1^{\mathrm{a}}$
\end{tabular}

$\begin{array}{llllll}\text { EMJF } & 8.1^{\mathrm{a}} & 7.7^{\mathrm{ab}} & 8.1^{\mathrm{a}} & 8.5^{\mathrm{a}} & 8.1^{\mathrm{a}}\end{array}$

$\begin{array}{llllll}\text { KMJF } & 8.0^{\mathrm{a}} & 8.1^{\mathrm{a}} & 8.0^{\mathrm{a}} & 8.7^{\mathrm{a}} & 8.2^{\mathrm{a}}\end{array}$

LSD at $0.05 \quad \mathrm{NS} \quad \mathrm{S} \quad \mathrm{Ns}$ NS

Means based on 9 points scale (9: Excellent, 1: Extremely bad), Means within the same column having the same letters are not significantly different ( $p \geq 0.05)$ according to the Duncan's multiple range tests, LSD: Least significant difference, NMJF: Nyala mangos jam fruits, EMJF: Edelfursan mangos jam fruits, KMJF: Kaboom mangos jam fruits

ranges of (5-11 and $4.5-11 \%)$ reported by Saeed and Elmubarak; Ahmed ${ }^{8}{ }^{16}$, respectively. The reducing sugar contents of NMJF, EMJF and KMJF are 4.6, 4.8 and $4.5 \%$, respectively. The data are agreement with range of (1.3-5.0\%) found by Abdelwahab et al. ${ }^{15}$. However, Ahmed ${ }^{17}$, reported that reducing sugars in jam were not less than $4.5 \%$.

The mean score for sensory attribute of jam prepared from different types of mango fruits are presented in Table 4. The data indicated that all types of jams were accepted by the panelist. Also, there are no significant differences as regard to appearance, colour, flavour and overall acceptability, while, there is significant difference as regard to texture.

\section{CONCLUSION}

It is concluded that, the KMF had a good quality in term of its physical characteristics. The sensory attribute of jam prepared from different types of mango fruits revealed that there are no significant difference as regard to appearance, colour, flavour and overall acceptability. 


\section{REFERENCES}

1. Pleguezuelo, C.R.R., V.H.D. Zuazo, J.L.M. Fernandez and D.F. Tarifa, 2012. Physico-chemical quality parameters of mango (Mangifera indica L.) fruits grown in a mediterranean subtropical climate (SE Spain). J. Agric. Sci. Techol., 14: 365-374.

2. Sakhale, B.K., R.U. Chalwad and V.D. Pawar, 2012. Standardization of process for preparation of fig-mango mixed toffee. Int. Food Res. J., 19: 889-891.

3. MOAF, 2008. Annual report of the horticulture administration. Khartoum, Sudan.

4. Pyler, E.J., 1973. Baking Science and Technology. 2nd Edn., Sieble Publishing Co., Chicago.

5. AOAC, 1985. Official Methods of Analysis. 14th Edn., Association of Official Analytical Chemists, Arlington, VA.

6. AOAC, 1990. Official Methods of Analysis. 15th Edn., Association of Official Analytical Chemists, Washington, DC., USA.

7. AOAC, 2005. Official Methods of Analysis of the Association of Analytical Chemists. 18th Edn., AOAC, Gathersburg, MD., USA.

8. Saeed, A. and A. Elmubarak, 1974. A guide to manufacture of jams for industry. Technical Report No. 3. Food Research Center, Khartoum, Sudan.

9. Pomeranz, Y. and C.E. Meloan, 1987. Food Analyst: Theory and Practice. 3rd Edn., Van Nastrand Reinfold Co., New York.

10. Iwe, M.O., 2002. Handbook of Sensory Methods and Analysis. 1st Edn., Rejoint Communication Services Ltd., Enugu, Nigeria, Pages: 71.
11. Snedecor, G.W. and W.G. Cochran, 1980. Statistical Methods. 7th Edn., Iowa State University Press, Ames, Iowa, USA., Pages: 507.

12. Anila, R. and T. Radha, 2003. Physico-chemical analysis of mango varieties under kerala conditions. J. Trop. Agric., 41: 20-22.

13. Uddin, M.Z., M.A. Rahim, M.A. Alam, J.C. Barman and M.A. Wadud, 2006. A study on biochemical characteristics of different mango germplasms grown in the climatic condition of mymensingh. Int. J. Sustain. Crop Prod., 1: 16-19.

14. Joseph, K. and O.C. Aworh, 1991. Composition sensory and respiration during ripening and storage of edible wild mango (Irvingia gabonensis). Int. J. Food Sci. Technol., 26: 337-342.

15. Abdelwahab, A.S., A.E. Sulieman and S.B. ElHardallu, 2011. Extraction of pectin from some local fruits and its use in jam processing. Gezira J. Agric. Sci., 9: 92-103.

16. Ahmed, H.M.O., 1999. Extraction fractionation and characterization of pectin substances of grapefruit peels. M.Sc. Thesis, Faculty of Agriculture, University of Khartoum, Sudan.

17. Ahmed, G.M.E., 2002. Utilization of grapefruit residue as pectin source in jam processing. M.Sc. Thesis, Faculty of Engineering and Technology, University of Gezira, Wad Medani, Sudan. 